\title{
リングせん断試験による残留状態の評価と 残留強度測定法に関する検討
}

\author{
酒井直樹 ${ }^{1} \cdot$ 豊田浩史 ${ }^{2} \cdot$ 中村公一 $^{3} \cdot$ 杉本光隆 ${ }^{4}$ \\ 1 学生会員 理修 長岡技術科学大学大学院 エネルギー・環境工学専攻 \\ (T940-2188 長岡市上富岡町1603-1) \\ 2 正会員 博士(工学) 長岡技術科学大学助教授 舞境・建設系 (T940-2188 長岡市上富岡町1603-1) \\ 3 学生会員 工修 長岡技術科学大学大学院 エネルギー・環境工学専攻 \\ （广940-2188 長岡市上富岡町1603-1） \\ ${ }^{4}$ 正会員 工博 長岡技術科学大学教授 環境・建設系（T940-2188 長岡市上富岡町1603-1）
}

\begin{abstract}
残留状態を達成するためには，リングせん断試験装置が最も適当であるといわれている. しかし，完全 な残留状態に必要なせん断変位打ち切り基準が不明確であることや，せん断中の間隙水圧測定が困難であ ることなど, 正確な残留状態の評価およびその強度測定の妨げとなる複数の要因が存在するため, リング せん断試験の試験方法は未だ確立していない，そこで本研究では，新たに改良したリングせん断試験装置 による定体積試験結果と三軸試験結果を比較することにより定体積試験の有効性を示した. 次に, 定体積 試験により有効応力経路を求めることで，せん断中に発生する間隙水圧を評価し，供試体の残留状態を実 験的に検証した. さらに, 以上の成果を用いて残留強度測定法について検討を行った.
\end{abstract}

Key Words : residual strength, ring shear test, constant volume, pore water pressure

\section{1.はじめに}

リングせん断試験は, 同一方向に対して変位を与 えることで残留強度 ${ }^{1)}$ 求めるための唯一の大変位 せん断試験2゙である. 残留強度の測定には, 供試体 に大変位を与え残留状態に至らしめることが必要で あり ${ }^{3)}$, その残留強度は試料を構成する粘土鉱物の 組成や，その粒子の配向によって支配される ${ }^{4)}$. し

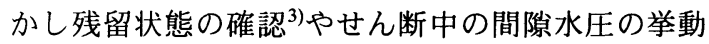
が強度に与える影響5)など，簡単には明らかにでき ないことも多い.

残留強度に至るまでのせん断挙動を応力変位関係 からみると, せん断応力が増加し, ピーク強度を迎 えた後, せん断応力が減少傾向を示しはじめる. そ の後はせん断変位が増加しても, ある一定の強度(残 留強度)を保つ曲線を描く. しかし, 試験機の機構に よりせん断応力が変動して一定值に収束しないため に, 応力変位曲線だけで残留状態を判断するのは難 しいとされている゙).

リングせん断試験機の特徵を一面せん断試験機と の比較から述べると, 供試体に対し一定方向へ無制 限に変位を与えられることが大きな利点 ${ }^{7}$ である. しかし一面せん断試験では, 定圧試験だけでなくせ ん断中の体積を一定に保つことで非排水試験と等価 な定体積試験 ${ }^{7}$ が確立されている. その定体積試験
では，せん断速度を大きく設定できるため，せん断 時間を短縮できるが, 定圧試験で行われるリングせ ん断試験では, せん断に長時間を有する.

残留強度測定に及ぼす影響を考察すると，この測 定法は, 定圧排水条件下での試験であるので, せん 断速度は間隙水圧の発生しない極力遅い速度で回転 させる必要 ${ }^{8}$ があり, せん断時間が長時間となる. この時, せん断時には上下拘束リング間にギャップ をあけているため(通常 $0.2 \mathrm{~mm}$ 程度), 試料の漏出は 避けられず6), 有効なせん断面の滅少や配向の乱れ につながることが考えられる. それに対して, ギャ ップを閉じてせん断を行う方法5)やギャップ間隔に 関する研究6)などが行われている. さらに, 残留強 度に影響を与える試験上の問題として, 拘束リング と供試体との間に発生する周面摩擦力によるせん断 ·面上の鈶直応力の変化 ${ }^{4), 9)}$ やせん断速度 ${ }^{1,9)}$ による影 響がある.

これまでに, 残留強度に関する多くの研究が行わ れてきているが, 残留状態を多面的に評価しながら, 推奖すべきリングせん断試験方法について検討した 例はない. そこで本研究では, まずはじめに, 定体 積リングせん断試験の適用性を, 非排水三軸圧縮試 験と対比することで検証する．次にせん断中の間隙 水圧挙動を, 定体積リングせん断試験を行うことに より間接的に評価するという手段を用いて供試体の 
残留状態を実験的に検証すると共に，有効で容易な 残留強度測定法に関しての検討を行う。

\section{2. 試料と試験方法}

\section{（1）試料}

試料は，市販の豊浦砂とカオリン粘土を使用した。 それぞれの粒度分布を，Fig. 1 に示す。豊浦砂 $\left(\rho_{\mathrm{s}}=2.65, \mathrm{e}_{\max }=0.990, \mathrm{e}_{\min }=0.597\right)$ は, リングせん断 試験では, 気乾状態のものを堆積させ, 振動により 密度を調整した。 三軸試験では, 湿潤締め固め法に より密度を調整し作製した．カオリン粘土は, 両試 験とも共通で, 含水比100\%のスラリーを脱気し, $75 \mathrm{kPa}$ で一次元圧密を約 4 日行った飽和度 $100 \%$ の 塊を成形して用いた。 その物性値を, Table 1 に示 す.

\section{（2）リングせん断試験}

試験装置の概要をFig.2に示す．拘束リングの外 径・内径はそれぞれ $15 \mathrm{~cm}, 10 \mathrm{~cm}$, 高さ $3 \mathrm{~cm}$, せん断面 は供試体下部から $1 \mathrm{~cm}$ のころに入る. せん断面が 供試体中央部でないのは, 試料の圧密や漏れを考慮 しているためである. 従来のビショップ型2)装置に 対して，以下に述べるような改良を行った. 最初に, 新たに回転盤の下に鈶直力・トルク兼用ロードセル を設置した．この改良により，せん断面に作用する 鈶直力とせん断力を直接測定することができる. 次 に上内外拘束リングに対して, 摩擦軽減のためテフ ロンコーティングを施した。これらの改良を施した ことにより，実験精度が大きく改善された ${ }^{10)}$ 。試験 条件は，定圧試験は鈶直応力を一定に保つことによ り, 定体積試験はロッドと加圧板を機械的に固定し, 加圧板の鈶直変位をなくす方法（鈶直変位は, $0.02 \mathrm{~mm}$ 以下） で行った. 加圧板固定後の鈶直応力の 緩和は，砂の場合はほとんどみられず，粘土の場合 は，二次圧密の影響により時間をおくとわずかに認 められる. せん断試験は, 圧密終了後加圧板を固定 の後, 速やかに行なった.

試験は, 初期せん断と残留せん断の 2 通りの方法 で行った．試料にせん断面が形成されていない状態 からのせん断 (初期せん断) は, 供試体をセット後, 拘束リング間のギャップを閉じたまま，所定の鈶直 応力で圧密を行う. 压密打ち切り時間は, 3 t法に従 った。 その後, 上下拘束リング間のギャップを,

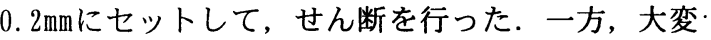
形を与えて試料にせん断面が形成された状態からの せん断 (残留せん断) は, 圧密終了までは初期せん断 と同じ過程で行い, その後, 試料漏出の影響を極力 少なくするため, ギャップを閉じたまま，定圧条件 のもと $0.4 \mathrm{~mm} / \mathrm{min}$ で 1 回転（360度）させて残留状態 を完成させた. ギャップを閉じてせん断を行うと, 上拘束リングと供試体の摩擦によりせん断面に作用 する正確な鈶直応力が，また，上下拘束リング間の 摩擦により正確なせん断応力が測定できなくなる.

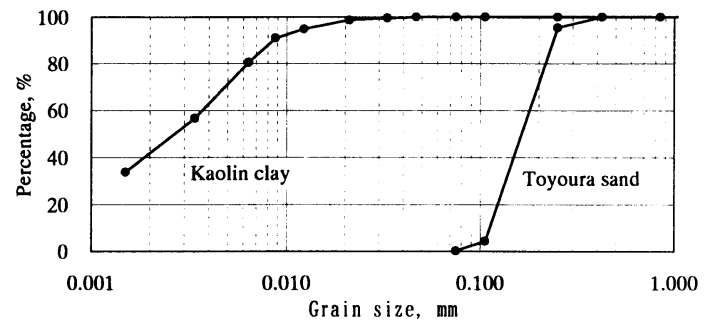

Fig.1 Grain size distribution

Table 1 Physical properties of Kaolin clay

\begin{tabular}{|c|c|c|c|c|}
\hline & $\begin{array}{c}\mathrm{w}_{\mathrm{L}} \\
(\%)\end{array}$ & $\begin{array}{c}\mathrm{w}_{\mathrm{P}} \\
(\%)\end{array}$ & $\mathrm{I}_{\mathrm{P}}$ & $\begin{array}{c}\rho_{\mathrm{S}} \\
\left(\mathrm{g} / \mathrm{cm}^{3}\right)\end{array}$ \\
\hline Kaolin clay & 47.0 & 29.8 & 17.2 & 2.70 \\
\hline
\end{tabular}

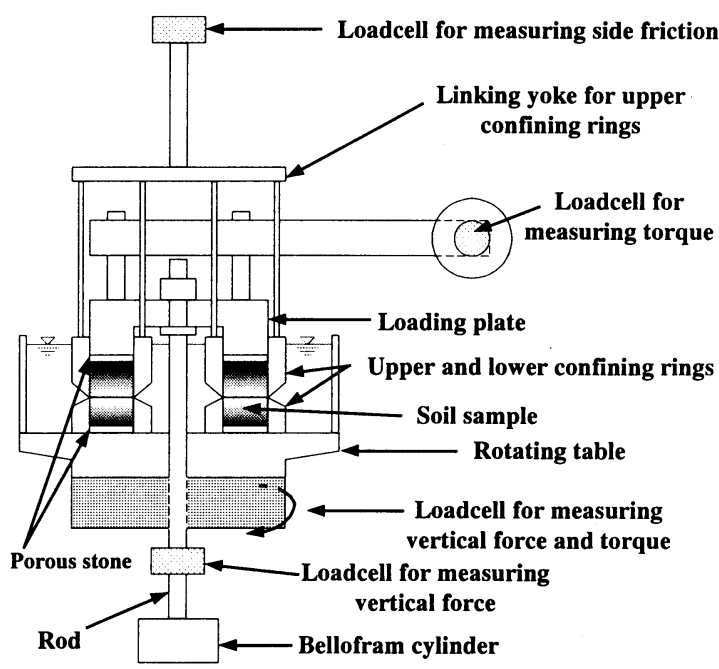

Fig.2 Schematic diagram of ring shear apparatus

Table 2 Test conditions of ring shear test

\begin{tabular}{|c|c|c|c|c|c|}
\hline & & $\sigma(\mathrm{kPa})$ & Condition & Case & $\begin{array}{c}\text { Shear rate } \\
(\mathrm{mm} / \mathrm{min})\end{array}$ \\
\hline \multirow{3}{*}{$\begin{array}{c}\text { Toyoura } \\
\text { sand }\end{array}$} & & 100 & $\mathrm{Dr}=30.2 \%$ & $\mathrm{CU}$ & 0.20 \\
\hline & & 100 & $\mathrm{Dr}=43.1 \%$ & $\mathrm{CU}$ & 0.20 \\
\hline & & 100 & $\mathrm{Dr}=57.0 \%$ & $\mathrm{CU}$ & 0.20 \\
\hline \multirow{11}{*}{$\begin{array}{c}\text { Kaolin } \\
\text { clay }\end{array}$} & \multirow{7}{*}{ 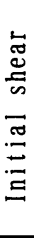 } & 100 & $0 \mathrm{CR}=1$ & $\mathrm{CU}$ & 0.20 \\
\hline & & 200 & $0 \mathrm{CR}=2$ & $\mathrm{CU}$ & 0.20 \\
\hline & & 300 & $0 \mathrm{CR}=3$ & $\mathrm{CU}$ & 0.20 \\
\hline & & 100 & $O C R=3$ & $\mathrm{CU}$ & 0.20 \\
\hline & & 100 & $0 \mathrm{CR}=6$ & CU & 0.20 \\
\hline & & 50 & $0 \mathrm{CR}=6$ & CU & 0.20 \\
\hline & & 200 & $0 \mathrm{CR}=1$ & $C D$ & 0.02 \\
\hline & \multirow{4}{*}{ 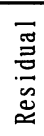 } & 100 & $0 \mathrm{CR}=1$ & $\mathrm{CU}$ & 0.20 \\
\hline & & 200 & $0 \mathrm{CR}=1$ & $\mathrm{CU}$ & 0.02 \\
\hline & & 200 & $0 \mathrm{CR}=1$ & $\mathrm{CU}$ & 0.20 \\
\hline & & 200 & $0 \mathrm{CR}=1$ & $C D$ & 0.02 \\
\hline
\end{tabular}



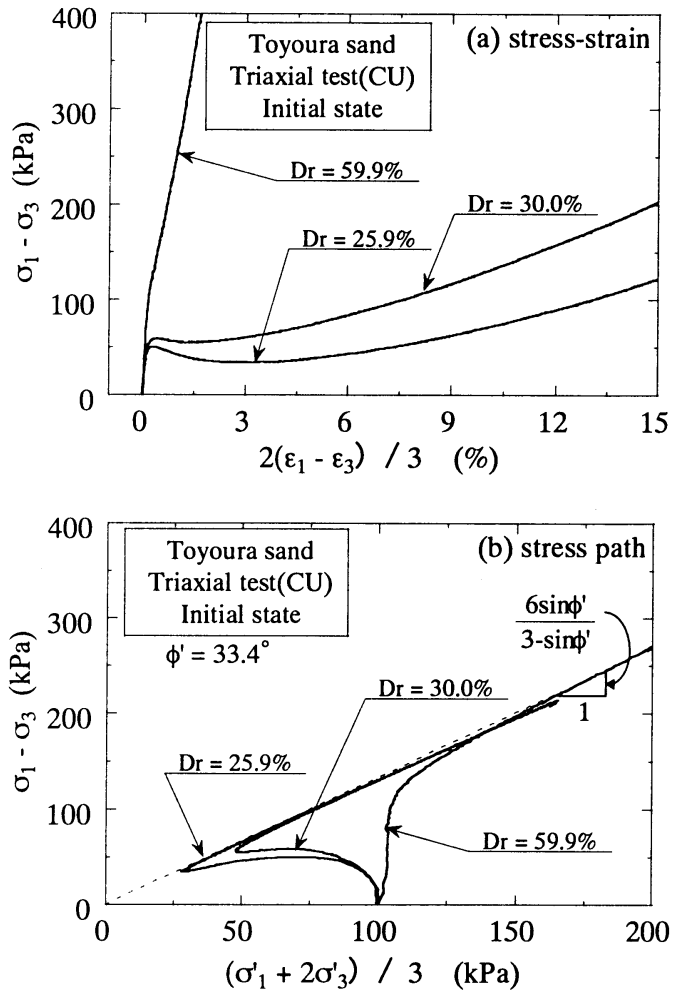

Fig. 3 Undrained triaxial compression tests in Toyoura sand.

しかしここでは，試料を漏出させず，せん断面に大 変位履歴を与えることを主目的とする．本せん断試 験時には，拘束リング間のギャップを $0.2 \mathrm{~mm} に セ ッ$ トして正確な残留強度測定を行っている.

本論文では, リングせん断における定圧条件を排 水条件と等価と考元CD条件と，定体積条件を非排水 条件と等価と考えCU条件と記載する。豊浦砂は密度 を変化させ, カオリン粘土は, 圧密応力や過圧密比 （OCR）を変化させ，試験を行った．試験条件をまと めたものを, Table 2に示す.

\section{（3）圧密非排水三軸圧縮試験}

試料には, リングせん断と同様, 豊浦砂, カオリ ン粘土を用いた。供試体サイズは直径 $5 \mathrm{~cm}$, 高さ $12 \mathrm{~cm}$ の円筒形である. 試験装置は一般的な三軸試験 機を用い，供試体の飽和には二重負圧法を用いた。 試験条件は，リングせん断試験と比較するために Table 2 と同様に行った.

\section{3. 試験結果と考察}

最初にリングせん断試験において，定体積条件に よる試験がどの程度まで成立するのかを三軸試験と の比較により検証した. 次に残留せん断については, 残留状態の達成状況と残留せ九断時の残留強度測定
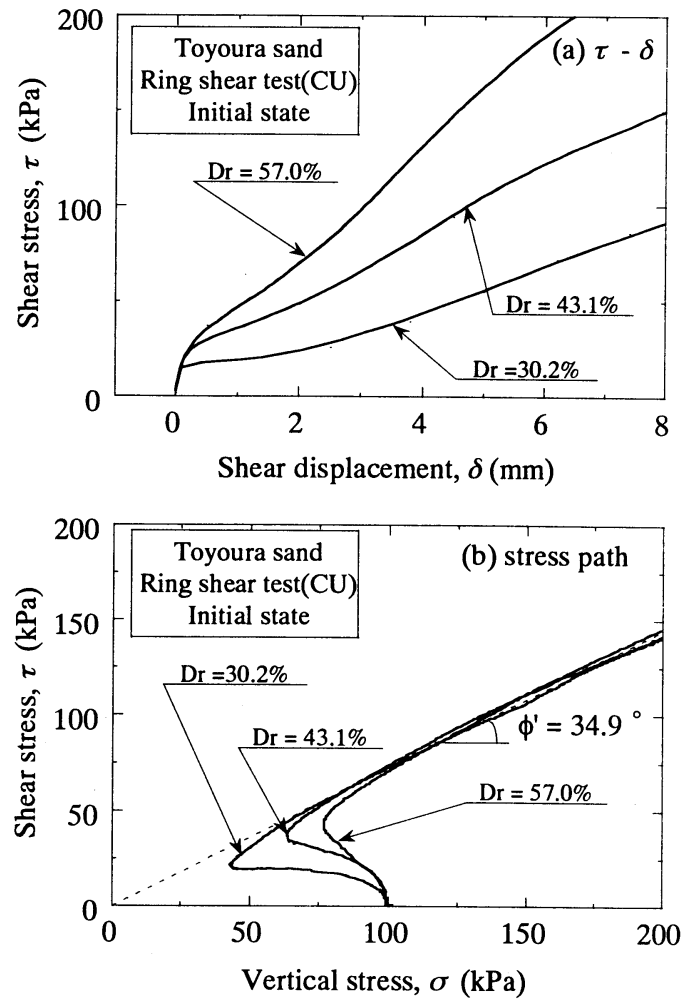

Fig. 4 Ring shear test under constant volume(CU) in Toyoura sand.

法に関して実験的に検討を行った.

\section{（1）リングせん断試験による定体積試験の検証 \\ a) 豊浦砂}

異なる密度の豊浦砂で行った圧密非排水三軸圧縮 試験結果をFig.3に，定体積リングせん断試験結果を Fig.4に示す.

Fig.3 (a)では, 相対密度Drの小さいものは, 比較 的低いピーク強度を示したあと，ひずみ軟化型の挙 動を示し，せん断ひずみが大きくなると徐々に強度 が増加する傾向を示している.この傾向はFig.4 (a) でも同様に見られ，相対密度が増えるに従い強度増 加が大きくなる傾向は，一致していることがわかる.

次にFig.3(b), Fig.4(b)で応力経路を比較する．相 対密度が大きくなるほど, 有効応力は増加傾向にあ るのが明らかであり, 変相点 (平均有効主応力 $p^{\prime}$ が 減少から增加に至る点）の位置も相対密度に応じて, 右にシフトする.これらの傾向は明らかに三軸試験 と同じ傾向を示しており, 定体積リングせん断試験 は三軸試験結果と定性的にほぼ同じ傾向を示すこと が明らかである.ただし，定体積リングせん断では, 相対密度の差によるこれらせん断挙動の違いが非排 水三軸圧縮試験に比べ, 小さくなる傾向が出ている.

b) カオリン粘土

カオリン粘土に対する非排水三軸試験結果をFig.5 に，定体積リングせん断試験結果をFig.6に示す．三 

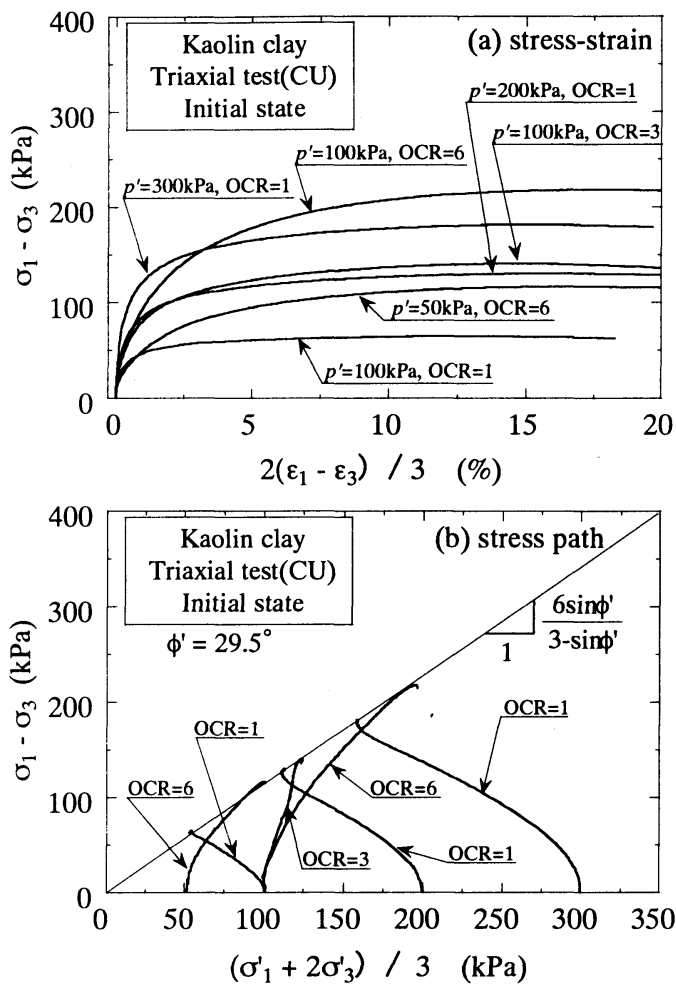

Fig. 5 Undrained triaxial compression test in Kaolin clay.

軸試験 (Fig.5(a)) の応力ーひずみ関係では, 正規圧密 $(0 \mathrm{CR}=1)$ でも, 過圧密でもひずみ硬化型を示し, ピ 一クはほとんど見られない. 同じ拘束圧のとき, 過 圧密比が大きくなればなるほど, 強度も大きくなる 傾向を示している.リングせん断の結果 (Fig.6(a)) でも，ほぼ同傾向を示している．さらにせん断変位 が大きくなってくると, ピークを示し若干の軟化傾 向を示している.

次に, 応力経路であるが, 両者の試験とも正規圧 密 $(0 C R=1)$ の場合, 有効応力が減少して破壊線に近 づいていくが，過圧密比が大きくなるほど，有効応 力が増加してくる傾向を示す. 両者の違いは限界状 態線に達した後の挙動であり, 三軸試験ではほぼ停 留し，リングせん断試験では限界状態線に沿って減 少しているのがわかる.これは, 明らかにせん断中 の試料漏出によるものであり, せん断変形が大きく なってくると, 試料漏出量を評価して鈶直変位を制 御しない限り, 厳密な定体積試験は行えないという ことである.ただし, 定体積リングせん断の結果は 非排水三軸圧縮試験の結果と似ていることより,

Fig.6(a)でのせん断応力が減少し始めるまで（せん断 変位が約 $5 \mathrm{~mm}$ 以下)，すなわち試料漏出によるせん 断応力の減少がかなり少ないときは, 非排水試験と 等価な試験ができているといえる.

\section{（2）残留状態の評価}

ここまでに，非排水三軸圧縮試験との対比の結果,
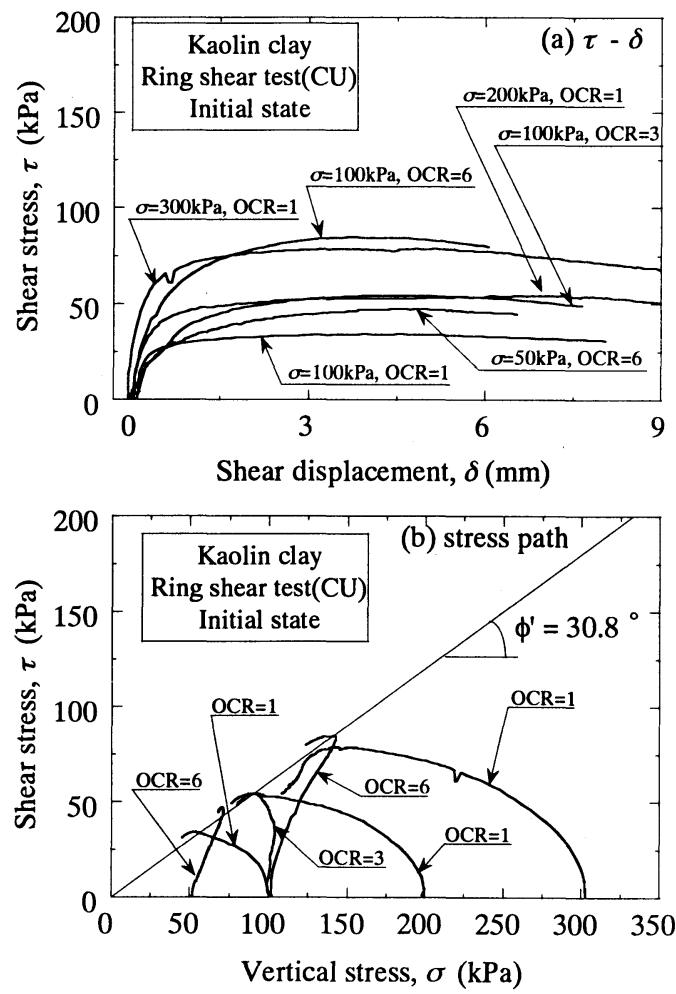

Fig. 6 Ring shear test under constant volume(CU) in Kaolin clay.

定体積リングせん断試験の有効性が明らかとなった. つまり, 定体積リングせん断試験を行えば, 間接的 に供試体中の間隙水圧の変化を評価できるというこ とである.

そこで, 大変位を与えて残留状態になった供試体 に対し,（鈶直応力, せん断変位速度 $)=(100 \mathrm{kPa}$, $0.2 \mathrm{~mm} / \mathrm{min}),(200 \mathrm{kPa}, 0.2 \mathrm{~mm} / \mathrm{min}),(200 \mathrm{kPa}, 0.02 \mathrm{~mm} / \mathrm{m}$ in）の 3 種類の定体積せん断試験を行った結果を Fig.7(a)に示す．最終的に20mmまでせん断したが, どれもピークより $10 \%$ 弱の減少が見られている.こ れは，機械的に加圧板を固定しているため，せん断 中の試料漏出が強度の減少をもたらしたと考えられ る.一方で, Fig.7(b)の応力経路をみてみると, せ ん断速度の影響はほとんど受けていないのがわかる. さらに, どのケースも鈶直応力 $\sigma$ 一定で残留状態線 まで上昇している．これは，せん断中に有効応力の 変化がないことを示唆している. ゆえに, この力オ リン供試体は大変形を受け, 残留状態に至っていた ものと判断できる. 通常の定圧リングせん断では, $0.02 \mathrm{~mm} / \mathrm{min}$ が標準とされているが，せん断による 有効応力の変化がないということは, 定圧せん断に おいても, 有効応力の変化を気にせず, 定体積せん 断試験のせん断速度程度でせん断しても問題ないと いうことである. さらに，即座に残留状態に達して いるので, 非常に短時間の測定のみで, 残留強度を 得ることができることがわかる．本研究では，力才 リン粘土のみで検証を行ったが，以上の結果を高塑 



Fig. 7 Residual state under constant volume conditions.

性粘土に適用するには，さらなる検討が必要である.

\section{（3）残留強度測定方法について}

残留強度測定方法に関して, 下記のように 3 種類 の方法で行ったせん断試験結果をFig.8 に示す.こ こで，鈶直変位 $\Delta H$ は圧縮の場合を正とした.

(i) 排水初期せん断試験 $(0.02 \mathrm{~mm} / \mathrm{min})$

(i i) 排水残留せん断試験 $(0.02 \mathrm{~mm} / \mathrm{min})$

(i i i ) 非排水残留せん断試験 $(0.2 \mathrm{~mm} / \mathrm{min})$

まず，初期せん断（i）の場合，Fig.8(a)ではせん断 変位の増加とともに徐々にせん断応力が増加し, $\delta=10 \mathrm{~mm}$ 程度でピークに達し(この状態でのせん断抵 抗角 $\left(30.4^{\circ}\right)$ は三軸試験から得られるせん断抵抗角 $\left(29.5^{\circ}\right)$ とほぼ等しい), その後徐々に減少して, $\delta=40 \mathrm{~mm}$ では，ほとんど残留状態に達したように見え る. Fig.8(b)では鈶直変位は，大きく増加しており， これは一般的な正規圧密粘土の挙動と一致する.さ らにせん断変位が進み, 残留状態区間 $\delta=50 \sim 60 \mathrm{~mm}$ は，強度は一定值を保っているように見えるが，試 料漏出のため, 鈶直変位は単調的に若干の増加を示 し，定常な残留状態の見極めが困難である。

排水残留せん断試験 (i i ) では，せん断開始後， $\delta=$ $1.2 \mathrm{~mm}$ 前後で最大值を迎えた後, ほぼ一定強度を保 っている (Fig.8(a))。これはFig.8(b)より は鈶直変位がゼロであることからも, 定常状態であ

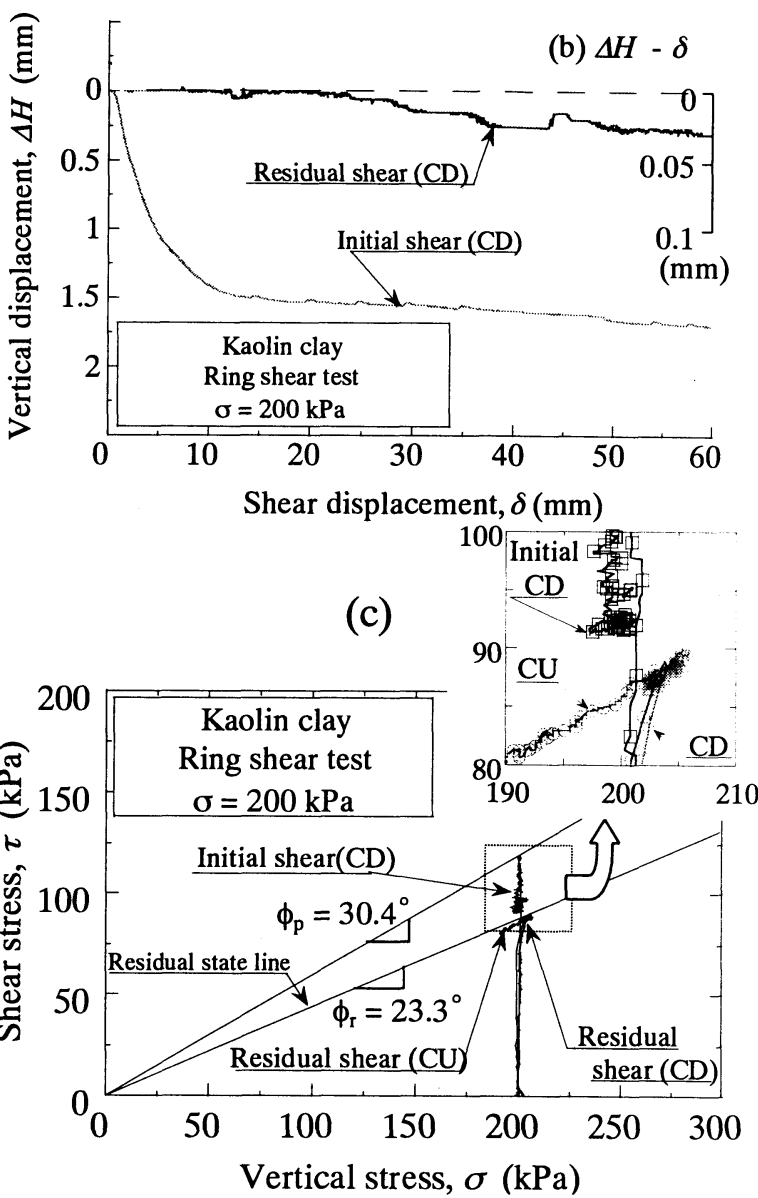

Fig. 8 Effects of shear conditions on residual state.

ることが推測できる. $\delta=20 \mathrm{~mm}$ 以降は， $\Delta \mathrm{H}$ はわずかで はあるが単調的な増加傾向を示す．これは, 供試体 がすでに残留状態に至っていることを考えると，試 料の漏出によるものと考えられる.このことから， 排水残留せん断試験の場合, $\delta=20 \mathrm{~mm}$ までは, 試料漏 出の影響のない, 安定で正確な残留強度を測定でき ていると考えられる. その後は, 試料漏出が発生し, 究極的な残留状態に近づいていくとは言い難い. 一 
方で非排水残留試験（ｉｉ）では，機械的に鈶直変位 を拘束しているため, 試料漏出の影響は, 有効鈶直 応力の低下として現れる (Fig.8(c)).

Fig.8(c)よりわかるように, 排水初期せん断 (i) で は, ピークを迎えた後, せん断応力が低下し, 残留 状態線に向かうが，排水残留せん断（i i )では，単調 的に残留状態線に沿っている. 非排水残留せん断 （i i i )においては, 排水残留せん断（i i ) と同じ経路 をたどって残留状態線に至っており, 有効応力が変 化しない，つまり，供試体はすでに定常な残留状態 に至っていたことが推測できる. なお, 残留状態線 は, $c_{\mathrm{r}}=0$ を仮定して図中の 3 通りの試験結果より, 求めている.

拘束リングを閉じた状態で残留状態を達成した後, 拘束リング間のギャップを開けて, 残留強度を求め る測定法に対して, 定圧, 定体積リングせん断試験 を行い, どちらでも同一な残留強度を測定できるこ とを示した. また, 残留せん断試験で, 拘束リング 間のギャップを開けた後は, 小さなせん断変位で残 留状態に至り, 残留状態を達成するために大変位は 必要ないことを明らかにした。ささらに, 残留状態に 達した供試体は, 有効応力が変化しないので, 定圧 条件であっても定体積条件と同じように高速のせん 断が可能である.

\section{4. まとめ}

非排水三軸圧縮試験と比較することにより, 改良 したリングせん断試験装置で, 定体積リングせん断 試験が行えることを検証した。 さらに，ギャップを 閉じたままのせん断で残留状態を再現できるかどう かの検証も行った.

完全な残留状態を形成させるときには, 試料漏出 を防ぐため, 拘束リング間のギャップを閉じてせん 断を行うと効果的である. 一度このような残留状態 が形成されると, せん断による有効応力の変化がな いことを実験により示した. 以上より, 残留状態形 成後は定圧試験でも定体積試験と同等なせん断速度 で行うことが可能であり, 試験時間の大幅な短縮と なる. 逆に, 試料漏出量が大きい場合は, 究極的な
残留状態に至っているかどうかの判定が困難である ため, 無駄に時間を消費している可能性もあり, 残 留強度の試験方法に注意する必要がある.

謝辞 : 元長岡技術科学大学学部生のZainondin, M君に は実験に関して数々の御協力をいただきました.こ こに記して感謝の意を表します。

\section{参考文献}

1) Skempton, A. W.: Residual strength of clays in landslide, folded strata and the laboratory, Geotechnique, Vol. 35-1, pp.3-18, 1985.

2) Bishop, A. W., Green, G. E., Garga, V. K., Anderson, A. and Brown, J. D.: A new ring shear apparatus and its application to the measurement of residual strength, Geotechnique, Vol. 21-4,pp. 273-328,1971.

3) 鈴木素之, 梅崎健夫, 川上浩: リングせん断試験におけ る粘土の残留強度とせん断変位の関係, 土木学会論文 集, No.575/III-40, pp.141-158, 1997.

4) 宜保清一: 地すべりと土質強度（その2）-残留強度特 性-, 地すべり技術, Vol.27-2, pp.17-27, 2000.

5) 矢田部龍一, 八木則男, 榎明潔: 破砕帯地すべり地の粘 性土のリングせん断特性, 土木学会論文集, No.436/III 16, pp.93-101, 1991 .

6) 宜保清一: 残留強度測定のためのリングせん断試験装 置とその測定精度, 地すべり, No.31-3, pp.24-30, 1994.

7) 土質試験の方法と解説, 地盤工学会, 2000 .

8) Lupini, J. F., Skinner, A. E. and Vaughan, P. R.: The drained residual strength of cohesive soils, Geotechnique, 31(2), 181-213,1981.

9) 鈴木素之, 梅崎健夫, 川上浩, 山本哲朗: 直接せん断試験 における土の残留強度, 土木学会論文集, No.645/III -50, pp.37-50, 2000.

10) 中村公一, 豊田浩史, 酒井直樹, 杉本光隆: 改良したリ ングせん断試験装置による定体積試験, 第20回土木学会 関東支部新潟会研究調査発表会論文集, pp.73-76, 2002.

(2002. 5. 29 受付)

\title{
VERIFICATION OF RESIDUAL STATE AND DETERMINATION OF RESIDUAL STRENGTH IN RING SHEAR TESTS
}

\author{
Naoki SAKAI, Hirofumi TOYOTA, Kouichi NAKAMURA and \\ Mitsutaka SUGIMOTO
}

\begin{abstract}
The residual state means ultimate steady shear state after large deformation. The ring shear apparatus is considered to be the most suitable apparatus for forming this state in soils. However, a standard of ring shear tests has not been established, because shear deformation to reach the residual state is not clear; also, it is very difficult to measure pore water pressure in soils during shearing. First of all, the effectiveness of constant volume tests in ring shear tests was demonstrated in this study. Then, the residual state was not verified based on measuring pore water pressure but based on stress path obtained from constant volume tests. Finally, effective and simple methods to measure the residual strength were proposed.
\end{abstract}

